\title{
Evaluation of Student Selection Test Model of Sports-Specific Class
}

\author{
Tri Hadi Karyono \\ Faculty of Sport Sciences \\ Universitas Negeri Yogyakarta \\ Yoyakarta, Indonesia \\ trihadikaryono@uny.ac.id
}

\begin{abstract}
- the objective of this study was to evaluate the students' selection test model implementation of Sports-Specific Class (Kelas Khusus Olahraga-KKO) of Junior and Senior High School in Yogyakarta. Survey research method was used in this study. The respondents of this study were administrators (superintendent and teacher) and coaches. Data collation was through the questionnaire method. The indicators used in the questionnaire include the physical, biochemical and psychological condition of the students. This study used a mix method design. The result data showed that $14.3 \%$ of respondents stated that the selection model was poor, $\mathbf{5 0 . 7 5 \%}$ quite good, and $34.95 \%$ good. Based on data analysis, it can be concluded that the selection test model used included in the quite good category. further development and improvement are required in order to obtain maximum results in selecting new students who will register in sports-specific class.
\end{abstract}

Keywords—model, selection, sports, student.

\section{INTRODUCTION}

The quality of education in Indonesia basically is still at a macro level. There is still need for improvement. Many factors are responsible for the sluggishness in the improvement of the quality of education in Indonesia. Human resources, educational facilities, economic conditions and fitness, the backwardness of information and geographical remoteness are some of the factors responsible for the poor the quality of education in Indonesia. This is why the government as an education manager has worked hard to improve the quality of education through improvement programs. The first step of improving education is a learning process in the classroom. The learning process will be more effective if supported by adequate conditions of facilities and infrastructure, reliable resources and excellent health conditions of students. Improving student health conditions can be supported by several activities, including through regular and needed sports activities. Activities that are more directed to the learning process have been carried out in schools through programs contained in the curriculum of sports and health physical education subjects.

At the time of this research, national sports achievements are not encouraging as they are still in a lagging state, it basically illustrates that sports training in schools and sports implementation have not been properly implemented, optimally and programmed.

Therefore, students can develop sports achievements in order to improve the quality of sports as well as empower schools. This needs to be supported by a program that can accommodate these activities.

Sports can also obtain better achievements with the number of events or tournaments held. Both at the district,

\author{
Abdul Alim \\ Faculty of Sport Sciences \\ Universitas Negeri Yogyakarta \\ Yoyakarta, Indonesia \\ abdulalim@uny.ac.id
}

provincial and national levels even at the international level. This shows that more opportunities are open to communities in developing the talents, interests, self-development, and opportunities for the achievement of their athletes.

An education program (including a sports class program) is always influenced by various components that are interrelated with each other. These components are subsystems in the educational system. If you want to develop certain sub-systems, changes must be made to other subsystems. There are at least 8 components that need to be directed to support the achievement of the program. These components include (1) Students (2) Curriculum, (3) Educators and Education Personnel, (4) Facilities, (5) Funds, (6) Management, (7) Environment, and (8) the Process of learning how to teach.

The existence of a sports class at school will help students who have abilities in the field of sports to be able to develop their potential according to the schedule, instructions, and direction of the trainer in school without neglecting academic subjects. Training with students' academic learning must be put into due consideration. Therefore, the Directorate General of Primary and Secondary Education Management, Ministry of National Education, programmed these activities to be organized in schools.

To achieve optimal performance coaching, it starts at the lower level and through careful planning. In the Yogyakarta Special Region, there is already an achievement coaching that starts from the junior high school level through Special Sports Classes (KKO) at junior high and high school level. Schools in Yogyakarta that have organized KKOs include: SMP N 1 Kalasan, SMP N 2 Tempel, SMP N 13, and Kretek Middle School, while at high school level includes SMA N 2 Ngaglik, SMA N 1 Sayegan, SMA N 1 Sewon, SMA N 4 Yogyakarta, SMA N 1 Pengasih, SMA N 2 Playen, and SMA N Tanjung Sari.

Efforts to improve achievement through the actualization of achievement in schools is meaningless if the implementation of achievement coaching in the High School $\mathrm{KKO}$ is not going well, so there needs for evaluation of the implementation of achievement training in schools so that the effectiveness of achievement training in schools can be known. Moving on from this thought, researchers will examine the achievement of high school KKO achievements in DIY.

Special Sports Classes are held to develop students' interests and talents in the field of sports. This is in correspondence with the government's statement through Ditjend Dikdasmen (2010), the purpose of Special Sports Classes which aims to (a) develop students' talents and 
interests in the field of sports, (b) enhance academic quality and sports performance, (c) improve competition skills in a sporty manner, (d) improve the school's ability to foster and develop sports activities, (e) improve physical and spiritual health, and, (f) improve the quality of education as part of character building.

\section{METHOD}

This research is a descriptive quantitative method. The population in this study were all KKO students in Yogyakarta. The sampling technique used in this study is the population sampling technique. This study aim is to evaluate the student selection test model of KKO.

\section{RESULTS AND DISCUSSION}

TABLE I. ACHIEVEMENT KKO MEAN ANALYSIS RESUlT

\begin{tabular}{|c|c|}
\hline Percentage & Explanation \\
\hline $14,3 \%$ & Poorly \\
\hline $50,75 \%$ & Quite good \\
\hline $34,95 \%$ & Good \\
\hline
\end{tabular}

The table above shows that according to the Evaluation Result the instrument was quite good with the percentage of $50.75 \%$. These results indicate that the instruments used are good enough to evaluate sports class-specific services

The existence of the Special Sports Classes does not disrupt the existing school or education program, the main factor is that the training process and sports achievement training are more programmed, organized, organized and optimized. Like the general class, in the process of learning Special Classes for Sport still refers to the applicable curriculum set by the school. In the formation of special sports classes, there needs to be a structured and good management for the smooth running of special sports class programs. In the special sports classes' management, various components influence the smooth running of special sports talent programs. Special sports classes have the target of fostering and developing students' talents and interests in the field of sports improve academic quality and sports performance, improve the ability to compete competitively, improve the ability of schools to foster and develop sports activities. The expected result is a special sports class, namely the implementation of training and the development of potential students in the field of sports so that it can improve sports and academic achievements.

\section{CONCLUSION}

Valid evaluation instruments for special sports class management services are needed in order to control the implementation of special sports class services in order to achieve the objectives of the special sports class.

\section{REFERENCE}

[1] Undang-Undang Keolahragaan Nasional pasal 25 tahun 2005.

[2] Wahjoedi, "Evaluasi Pendidikan Jasmani". Rineka Cipta. Jakarta, 2001.

[3] D. P. Irianto, "Dasar Kepelatihan". Yogyakarta: FIK UNY, 2002.

[4] S. Junaidi, "Pembinaan olahraga usia dini". Semarang: Universitas Negeri Semarang, 2003.

[5] T. O. Bompa, "Theory and Methodology of Training". Debuque, Iowa: Kendall/Hunt Publishing, 1990. 